\title{
Debt Policy and Corporate Performance: Empirical Evidence from Tehran Stock Exchange Companies
}

\author{
Nima Sepehr Sadeghian ${ }^{1}$, Mohammad Mehdi Latifi ${ }^{2}$, Saeed Soroush ${ }^{3} \&$ Zeinab Talebipour Aghabagher ${ }^{4}$ \\ ${ }^{1}$ Faculty of Management and Accounting, Shahid Beheshti University, Evin, Iran \\ ${ }^{2}$ Faculty of Management, University of Tehran, Tehran, 631114155, Iran \\ ${ }^{3}$ Financial Management, School of Finance, University of Economic Sciences, Iran \\ ${ }^{4}$ Faculty of Management and Social Sciences, Islamic Azad University- North Tehran Branch, Tehran, Iran \\ Correspondence: Mohammad Mehdi Latifi, Faculty of Management, University of Tehran, Tehran, 631114155, \\ Iran. Tel: 98-93-7016-0461. E-mail: mehdi.latifi@yahoo.com
}

Received: June 18, 2012 Accepted: October 4, $2012 \quad$ Online Published: October 17, 2012

doi:10.5539/ijef.v4n11p217 URL: http://dx.doi.org/10.5539/ijef.v4n11p217

\begin{abstract}
The ability of companies in determining suitable financial policies to make investment opportunities is one of the most principal factors for the companies' growth and progression. Adopting a debt policy or a capital structure is considered as a momentous decision that influences the companies' value. This paper is aimed to investigate the probable relationship between debt policies (including Current Debt, Non-Current Debt, and Total Debt) and performance of Tehran Stock Exchange Companies. The regression model is applied to investigate the relationship between the performance indicators and debt ratios. In this research, financial performance indicators are considered as Gross Margin Profit, Return on Assets (ROA), Tobin's Q Ratio, and Debt Ratios (Current Debt, Non-Current Debt, and Total Debt). "size" and "growth rate" are considered as control variables. Results show that an increase in current debts, non-current debts, and total debts has a negative influence on the corporate performance. It was also found that companies that merely attempt to create assets through debts, without any attention to the company size and other important factors, are not able to have an excellent performance.
\end{abstract}

Keywords: performance, debt policy, gross margin profit, Return on Assets (ROA), Tobin's Q Ratio, debt ratios

\section{Introduction}

The influence of debt policies on the corporate performance is determinant for an appropriate capital structure and is a critical decision for any business. The fast-changing nature of the modern business environment means that planning should be a continuous (Latifi et al, 2010). Businesses have to prepare themselves to react to a wide range of probable futures (Hamidizadeh et al, 2012). As strategic planning is a suitable tool to reach organizational goals (Latifi et al. 2012), results of the current research are very important, not only due to the need to maximize returns to various organizational constitutions in Iran, but also because of its impact on the organization's ability to deal with its competitive environment (Dare Funso David and Sola Olorunfemi). If the firm's capital structure influences its performance, it will be reasonable to expect that the firm's capital structure can influence its health and its likelihood of default.

From both Investors' and creditors' viewpoints, corporate performance evaluation provides a basis to measure the managerial success. Creditors regularly analyze the firm's performance in order to determine the volumes and rates for providing financial resources. Debt ratios help creditors understand the firm's risk management strategies as well as conservative /aggressive approaches toward current and non-current assets and liabilities. The investor's acquired return on equity illustrates management's ability in utilizing investments. The examination of debt policy and corporate performance contributes the management that always attempts to optimize the debt to equity ratio to create sustainable wealth not only for investors but for all stakeholders. While several electronic systems including internet have changed the communication world and given particular opportunities to communication ways, (Hamidizadeh et al, 2012), in this paper, the relationship between debt policy and performance of Tehran Stock Exchange companies are empirically investigated using some performance indicators such as Gross Profit Margin, Return on Assets (ROA), and Tobin's Q Ratio. 


\section{Literature Review}

El-Sayed Ebaid, (2009) investigated the impact of capital structure choice on firm performance in Egypt as one of emerging or transition economies. Using three of accounting-based measures of financial performance (i.e. return on equity (ROE), return on assets (ROA), and gross profit margin), and based on a sample of non-financial Egyptian listed firms from 1997 to 2005 the results revealed that capital structure choice decision, in general terms, has a weak-to-no impact on firm's performance.

Abor, (2005) examined the relationship between capital structure and profitability of listed firms on the Ghana Stock Exchange (GSE) during a five-year period. The results represented a significantly positive relation between the ratio of short-term debt to total assets and ROE. However, a negative relationship between the ratio of long-term debt to total assets and ROE was found.

Qi, Wu and Zhang (2000) investigated whether and how the corporate performance of listed Chinese firms is affected by their shareholding structure. Their findings suggested that the ownership structure composition and relative dominance by various classes of shareholders can affect the performance of state-owned enterprise (SOE)-transformed and listed firms.

Majumdar and Chhibber, (1999) examined the relationship between the levels of debt in the capital structure and performance for a sample of Indian firms. Analysis of the data revealed this relationship for Indian firms to be significantly negative.

Berger and Bonaccorsi di Patti, (2004) examined the impact of leverage on agency costs and thereby the firm performance. In today's economic climate, there is an increasing emphasis on cost reduction and increased efficiency (Latifi et al, 2011). They also proposed a new approach to test the agency theory using profit efficiency. Considering that Investment banking firms are intermediaries that can fund different sectors (Latifi et al, 2012), the results showed that data on the US banking industry are consistent with the theory, and the results are statistically significant, economically significant, and robust.

Gleason, Knowles Mathur and Mathur, (2000) investigated the Interrelationship between Culture, Capital Structure, and Performance for European Retailers. Using both financial and operational measures of performance, it was shown that capital structure influences financial performance, although not exclusively. A negative relationship between capital structure and performance suggested that agency issues may lead to use of higher than appropriate levels of debt in the capital structure, thereby producing lower performance.

Margaritis and Psillaki, (2010), investigated the relationship between capital structure, ownership structure and firm performance across different industries using a sample of French manufacturing firms. They found support for the core prediction of the agency cost hypothesis in that higher leverage is associated with improved efficiency over the entire range of observed data. They also found evidence to support the hypothesis that firms with more concentrated ownership face lower agency costs only in chemicals industry. No statistically significant relationship between ownership structure and firm performance in the computers and textiles industries was observed.

David and Olorunfemi, (2010) examined the impact of capital structure on corporate performance in the Nigerian Petroleum Industry. The study employed panel data analysis by using Fixed-effect estimation, Random-effect estimation and Maximum likelihood estimation. It was found out that there was positive relationship between earnings per share and leverage ratio on one hand and positive relationship between dividend per share and leverage ratio on the other hand.

\section{Research Hypotheses}

In this study, Gross Profit Margin, Return on Assets (ROA), and Tobin's Q Ratio are applied to measure the corporate performance of Tehran Stock Exchange Companies. If the capital structure influences the firm's performance, the correlation between debt policies and firm's performance can be expected. We argue that debt maturity ratios (current debt, non-current debt, and total debt), as a proxy for firm's debt policies, will influence the corporate performance. Using a gross profit margin as an indicator of a firm's performance, the hypotheses are as follows:

$\mathrm{H}_{1}$ : There is a negative significant relationship between firm's short-term debt policy and its gross profit margin.

$\mathrm{H}_{2}$ : There is a negative significant relationship between the firm's long-term debt policy and its gross profit margin.

$\mathrm{H}_{3}$ : There is a positive significant relationship between the firm's total debt policy and its gross profit 
Since the performance measure ROA is widely regarded as the most useful measure to test firm's performance (Reese and Cool, 1978 and Long and Ravenscraft, 1984, Abdel Shahid, 2003, among others), the hypothesis to be tested are as follows:

$\mathrm{H}_{4}$ : There is a negative significant relationship between the firm's short-term debt policy and its return on assets.

$\mathrm{H}_{5}$ : There is a negative significant relationship between the firm's long-term debt policy and its return on assets.

$\mathrm{H}_{6}$ : There is a positive significant relationship between the firm's total debt policy and its return on assets.

Tobin's Q Ratio is used to represent firm's performance in many studies (e.g., Morck, Shleifer, and Vishny, 1988, McConnel and Serveas, 1990, and Zhou, 2001). So, the hypotheses $\mathrm{H}_{7}$ to $\mathrm{H}_{9}$ can be introduced as the following:

$\mathrm{H}_{7}$ : There is a negative significant relationship between the firm's short-term debt policy and Tobin's Q Ratio.

$\mathrm{H}_{8}$ : There is a negative significant relationship between the firm's long-term debt policy and Tobin's Q Ratio.

$\mathrm{H}_{9}$ : There is a positive significant relationship between the firm's total debt policy and Tobin's Q Ratio.

\section{Methodology}

\subsection{Data and Sample}

In this study, the corporate performance of Tehran Stock Exchange Companies is investigated between the years 2006 to 2011. The sample should have the following characteristics:

1- All companies were required to deliver their financial statements for each year between 2006 and 2011. They were also supposed to give the historical stock price at the end of each year.

2- All financial institutions were excluded from the research population because of their different nature of operations.

3- Selected companies had to have an identical ending of the fiscal year for all years between 2006 and 2011 due to the comparability of analyzed data.

4- We screened some companies because of the lack of the required research data.

A quantitative approach using a co-relational research design is used in this study.

As data are collected using tools such as observation and questionnaire this research is a scientific study which seeks to solve practical problems and as its aim is to develop practical knowledge in investigating debt policy and corporate performance of Tehran Stock Exchange Companies, it can be considered as an applied research. Results of this research can be applied to solve the problems that exist among Iranian managers from the registered corporations in Tehran Stock Exchange. On the other hand, as the current research is designed to provide further insight into the research problem by describing the variables of interest, and typically involves conducting a survey of a sample of population elements at one point in time, it can be considered as a descriptive research. As this study is an intensive study of a single unit with an aim to generalize across a larger set of units, its method is qualitative with small-N, is ethnographic with participant-observation, is "in the field", and is characterized by process-tracing, it can be considered as a case study research.

\section{Data Analysis}

Gujarati (2007) states that there are three types of data available for an empirical analysis: time series data, cross-sectional data, and pooled data (i.e., combination of time series and cross-sectional). Since the variables are selected from various companies between 2006 and 2011, the type of data for this study can be considered as pooled. There are two approaches to analyze pooled data which include classical linear regression model and panel data regression model. In order to use the classical linear regression model, all firms' data should be considered as homogeneous; otherwise the panel data should be applied. F Limer Test is employed to determine which method must be utilized to analyze pooled data. Fisher's F distribution is applied to identify whether the linear regression model between independent and dependent variables is statistically significant. There are two approaches to estimate panel data: The Fixed Effects Model (FEM) and The Error Components Model (ECM). The existence of correlation among error components and explanatory variables determines the right model to be selected. If it is assumed that $\varepsilon \mathrm{i}$ (error component) and the X's (regressors) are not correlated, ECM may be appropriate, whereas if $\varepsilon i$ and the X's are correlated, FEM may be appropriate. In this study, Hausman test would help to choose between FEM and ECM. The null hypothesis underlying the Hausman test is that the FEM and ECM estimators do not differ substantially. If the null hypothesis is rejected, ECM would not be appropriate and that it would be better to use FEM (Gujarati, 2007). 
The classical linear regressions model assumes that error terms are dependent over time. In some cases, however, error components are correlated in different time periods and such situation is called autocorrelation or serial correlation. The most popular test for detecting serial correlation is the one developed by Durbin and Watson. It is known as the Durbin-Watson d statistic, which ranges from 0 to 4 . The closer $d$ is to 0 , the greater the evidence of positive serial correlation; and the closer $\mathrm{d}$ is to 4 , the greater the evidence of negative serial correlation. If there is no serial correlation, $d$ is expected to be about 2 (Gujarati, 2007). Eventually, the $t$ Statistic is used to evaluate the significance of estimated regression coefficients and the mean of variables.

In this research, descriptive statistics methods are used to summarize and classify the gathered data and inferential statistics methods are applied to analyze them. Table 1 shows the descriptive statistics results of variables.

Table 1. Descriptive statistics of data

\begin{tabular}{|c|c|c|c|c|c|c|c|}
\hline Variable & Mean & Std. Deviation & Min. & Max. & Skewness & Kurtosis & Frequency \\
\hline Short-term Debt Ratio & 2.5686 & 3.360924 & -27.79 & 28.06 & -0.61 & 21.714 & 515 \\
\hline Long-term Debt Ratio & 0.3043 & 1.608205 & -30.84 & 12.1 & -13.88 & 296.297 & 488 \\
\hline Total Debt Ratio & 2.9855 & 5.058406 & -58.63 & 46.31 & -0.924 & 62.824 & 515 \\
\hline Corporation Size & 5.4478 & 0.608189 & 3.56 & 7.81 & 0.98 & 2.086 & 515 \\
\hline Sales Growth Rate & 0.2238 & 0.467488 & 0.9975 & 7.682 & 8.338 & 126.516 & 515 \\
\hline Gross Profit Margin & 0.1506 & 0.720533 & -15.51 & 1.12 & -20.353 & 442.822 & 507 \\
\hline Return on Assets & 0.1370 & 0.1407 & -0.32 & 0.59 & 0.281 & 0.986 & 515 \\
\hline Tobin’s Q & 1.0320 & 1.177798 & 0.06 & 9.46 & 3.356 & 14.711 & 515 \\
\hline
\end{tabular}

The most important measure that shows the balance point and is the exertion center of distribution is arithmetic mean (Azar et al, 2006). As it can be observed in table 1, the mean values of short-term debt ratio, long-term debt ratio, and total debt ratio are $2.5686,0.3043$, and 2.9855 respectively, the mean values for corporation size and sales growth rate are 5.4478 and 0.2238 , mean values of gross profit margin and return on assets are 0.1506 and 0.1370 , and the mean value for Tobin's Q is 1.0320 . The third column in table 1 shows the standard deviation of variables. The value of this parameter for total debt ratio is 5.0584, which is the highest among all variables. The value of a standard deviation for return on assets is 0.1407 which is the lowest of all.

After analyzing descriptive statistics of data, research hypotheses should be tested. Hypotheses have been tested according to data and the model which results are illustrated as table 2 .

Table 2. Test of the Modeling Validation

\begin{tabular}{|c|c|c|c|c|c|}
\hline Hypotheses & Test Type & Model's Significance Test & Limer's F Test & Hoffman Test & Durbin-Watson Test \\
\hline \multirow{2}{*}{ Hypothesis (1) } & Test Statistic & $(5.17) \mathrm{F}$ & $(1.5) \mathrm{F}$ & $(0.912) \mathrm{H}$ & (1.93) DW \\
\hline & P-value & 0.002 & 0.000 & 0.31 & - \\
\hline \multirow{2}{*}{ Hypothesis (2) } & Test Statistic & $(4.049) \mathrm{F}$ & $(1.7) \mathrm{F}$ & $(0.812) \mathrm{H}$ & $(1.932) \mathrm{DW}$ \\
\hline & P-value & 0.007 & 0.000 & 0.38 & - \\
\hline \multirow{2}{*}{ Hypothesis (3) } & Test Statistic & $(5.082) \mathrm{F}$ & $(1.62) \mathrm{F}$ & $(0.862) \mathrm{H}$ & $(1.932) \mathrm{DW}$ \\
\hline & P-value & 0.002 & 0.000 & 0.35 & - \\
\hline \multirow{2}{*}{ Hypothesis (4) } & Test Statistic & $(13.79) \mathrm{F}$ & $(1.92) \mathrm{F}$ & $(0.9543) \mathrm{H}$ & $(2.1242) \mathrm{DW}$ \\
\hline & P-value & 0.000 & 0.000 & 0.42 & - \\
\hline \multirow{2}{*}{ Hypothesis (5) } & Test Statistic & $(10.90) \mathrm{F}$ & $(1.6123) \mathrm{F}$ & $(0.9125) \mathrm{H}$ & $(0.654) \mathrm{DW}$ \\
\hline & P-value & 0.000 & 0.000 & 0.41 & - \\
\hline \multirow{2}{*}{ Hypothesis (6) } & Test Statistic & $(14.256) \mathrm{F}$ & $(1.9653) \mathrm{F}$ & $(0.9222) \mathrm{H}$ & $(0.701) \mathrm{DW}$ \\
\hline & P-value & 0.000 & 0.000 & 0.415 & - \\
\hline \multirow{2}{*}{ Hypothesis (7) } & Test Statistic & $(4.991) \mathrm{F}$ & $(1.695) \mathrm{F}$ & $(0.8765) \mathrm{H}$ & $(0.687) \mathrm{DW}$ \\
\hline & P-value & 0.002 & 0.000 & 0.385 & - \\
\hline \multirow{2}{*}{ Hypothesis (8) } & Test Statistic & $(4.354) \mathrm{F}$ & $(1.7654) \mathrm{F}$ & $(0.9116) \mathrm{H}$ & $(0.701) \mathrm{DW}$ \\
\hline & P-value & 0.005 & 0.000 & 0.4012 & - \\
\hline \multirow{2}{*}{ Hypothesis (9) } & Test Statistic & $(5.149) \mathrm{F}$ & $(1.8546) \mathrm{F}$ & $(0.8356) \mathrm{H}$ & $(0.689) \mathrm{DW}$ \\
\hline & P-value & 0.002 & 0.000 & 0.3901 & - \\
\hline
\end{tabular}


As it is observed in table 2, the significant levels of fisher's $\mathrm{F}$ test and limer's $\mathrm{F}$ test for all variables are under 5\% error. Therefore, it can be concluded that there is a regression relationship among variables and panel of data. The significant level of Hoffman test is above 5\% for all variables. Therefore, the null hypothesis (fixed effects) is rejected and the random effect is confirmed. Doorbin-Watson statistics show that the model of hypotheses 1 to 4 are not self-correlated, while the model of hypotheses 5 to 9 are self-correlated. With continuous and appropriate conversions, self-correlation will be modified and data will be ready for modeling.

Results of hypotheses 1 to 3 testing has been shown in table 3 .

Table 3. Results of Testing the Hypotheses 1,2, and 3

\begin{tabular}{|c|c|c|c|c|c|c|c|c|c|}
\hline \multicolumn{10}{|c|}{ Independent Variable: Gross Profit Margin (Model of Random Effects) } \\
\hline \multirow{2}{*}{ Variables } & \multicolumn{3}{|c|}{ Hypothesis 1 Testing Results } & \multicolumn{3}{|c|}{ Hypothesis 2 Testing Results } & \multicolumn{3}{|c|}{ Hypothesis 3 Testing Results } \\
\hline & Coefficients & t Statistic & P-value & Coefficients & t Statistic & P-value & Coefficients & t Statistic & P-value \\
\hline Y-Intercept & -0.249 & 2.62 & 0.001 & -0.233 & -0.756 & 0.45 & -0.249 & 2.075 & 0.021 \\
\hline SDC & -0.07 & -7.78 & 0.000 & - & - & - & - & - & - \\
\hline LDC & - & - & - & 0.0004 & 0.019 & 0.985 & - & - & - \\
\hline TDC & - & - & - & - & - & - & -0.1121 & 1.98 & 0.024 \\
\hline FS & 0.067 & 2.1 & 0.009 & 0.062 & 1.07 & 0.29 & 0.0062 & 0.054 & 0.225 \\
\hline SG & 0.24 & 3.505 & 0.000 & 0.227 & 3.14 & 0.002 & 0.238 & 3.479 & 0.001 \\
\hline $\mathrm{R}^{2}$ & 0.51 & 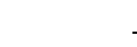 & & 0.25 & 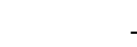 & & 0.501 & 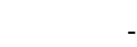 & \\
\hline
\end{tabular}

Considering the illustrated results in table 3, research hypotheses can be analyzed as the following:

Hypothesis 1 is significant and has a negative relationship with gross profit margin. This means as the shot-term debt increases, the profit margin will be decreased. In other words, 1 unit increase in a short-term debt will result in 0.07 unit decrease in a profit margin. Therefore, the model of the first hypothesis can be illustrated as the following:

$$
Y_{1}=-0.249-0.07 \text { SDCit }+0.067 \text { FSit }+0.24 \text { SGit }
$$

Although the results show that the second hypothesis is not significant, the effect of long-term debt is positively related to gross profit margin. This means that long-term debts increase the profit margin of a corporation. As second hypothesis is not significant, a model cannot be presented for it.

The third hypothesis is significant and has a negative relationship with a gross profit margin. This means that an increase in the total debt will result in a decrease in the profit margin of a corporation. In other words, 1 unit increase in total debt will result in 0.1121 unit decrease in a profit margin. Therefore, the model of the third hypothesis can be illustrated as the following:

$$
Y_{1}=-0.249-0.1121 \text { TDCit }+0.238 \text { SGit }
$$

Results of hypotheses 4 to 6 testing has been shown in table 4 .

Table 4. Results of Testing the Hypotheses 4, 5, and 6

\begin{tabular}{c|ccc|ccc|ccc}
\hline \multicolumn{8}{c}{ Independent Variable: Return on Assets Margin (Model of Random Effects) } \\
\hline \multirow{2}{*}{ Variables } & \multicolumn{2}{|c}{ Hypothesis 4 Testing Results } & \multicolumn{2}{c}{ Hypothesis 5 Testing Results } & \multicolumn{3}{c}{ Hypothesis 6 Testing Results } \\
\cline { 2 - 10 } & Coefficients & t Statistic & P-value & Coefficients & t Statistic & P-value & Coefficients & t Statistic & P-value \\
\hline Y-Intercept & 0.067 & 2.68 & 0.001 & -0.110 & -1.9298 & 0.029 & -0.091 & 0.686 & 0.048 \\
SDC & -0.0912 & 4.537 & 0.000 & - & - & - & - & - & - \\
LDC & - & - & - & -0.0921 & -2.301 & 0.000 & - & - & - \\
TDC & - & - & - & - & - & - & -0.021 & -2.1001 & 0.007 \\
FS & 0.05 & 1.98 & 0.021 & 0.004 & 0.36 & 0.72 & 0.019 & 1.901 & 0.034 \\
SG & 0.079 & 6.124 & 0.000 & 0.073 & 3.524 & 0.000 & 0.079 & 6.095 & 0.000 \\
R & 0.612 & & - & 0.583 & & - & & & - \\
\hline
\end{tabular}

Considering the illustrated results in table 4, research hypotheses can be analyzed as the following: 
The fourth hypothesis is significant and has a negative relationship with return on assets. This means that as the short-term debt increases, the corporation's return on assets will be decreased. In other words, 1 unit increase in short-term debt will result in 0.0912 unit decrease in return on assets. Therefore, the model of the fourth hypothesis can be illustrated as the following:

$$
Y_{2}=0.067-0.0912 \text { SDCit }+0.05 \text { FSit }+0.079 \text { SGit }
$$

The fifth hypothesis is significant and has a negative relationship with return on assets. This means that as the long-term debt increases, the corporation's return on assets will be decreased. In other words, 1 unit increase in long-term debt will result in 0.0921 unit decrease in return on assets. Therefore, the model of the fifth hypothesis can be illustrated as the following:

$$
Y_{2}=-0.110-0.0921 \text { LDCit }+0.073 \text { SGit }
$$

The sixth hypothesis is significant and has a negative relationship with return on assets. This means that as the total debt increases, the corporation's return on assets will be decreased. In other words, 1 unit increase in total debt will result in 0.021 unit decrease in return on assets. Therefore, the model of the sixth hypothesis can be illustrated as the following:

$$
Y_{2}=-0.091-0.021 \text { TDCit }+0.019 \text { FSit }+0.079 \text { SGit }
$$

Results of hypotheses 7 to 9 testing has been shown in table 5 .

Table 5. Results of Testing the Hypotheses 7, 8, and 9

\begin{tabular}{c|ccc|ccc|ccc}
\hline \multicolumn{8}{c}{ Independent Variable: Return on Assets Margin (Model of Random Effects) } \\
\hline \multirow{2}{*}{ Variables } & \multicolumn{2}{c}{ Hypothesis 7 Testing Results } & \multicolumn{2}{c}{ Hypothesis 8 Testing Results } & \multicolumn{3}{c}{ Hypothesis 9 Testing Results } \\
\cline { 2 - 10 } & Coefficients & t Statistic & P-value & Coefficients & t Statistic & P-value & Coefficients & t Statistic & P-value \\
\hline Y-Intercept & 2.105 & 4.529 & 0.000 & 2.228 & 4.504 & 0.000 & -2.106 & 4.533 & 0.000 \\
SDC & -0.033 & 2.1986 & 0.006 & - & - & - & - & - & - \\
LDC & - & - & - & -0.073 & -2.301 & 0.021 & - & - & - \\
TDC & - & - & - & - & - & - & -0.023 & -2.3 & 0.001 \\
FS & -0.202 & -2.354 & 0.019 & -0.229 & -2.52 & 0.012 & -0.203 & -2.373 & 0.018 \\
SG & 0.338 & 3.047 & 0.002 & 0.32 & 2.76 & 0.006 & 0.333 & 3 & 0.003 \\
R & 0.65 & & - & 0.63 & & - & 0.489 & & - \\
\hline
\end{tabular}

Considering the illustrated results in table 5, research hypotheses can be analyzed as the following:

The seventh hypothesis is significant and has a negative relationship with Tobin's Q. This means that as the short-term debt increases, the corporation's Tobin's Q ratio will be decreased. In other words, 1 unit increase in short-term debt will result in 0.033 unit decrease in Tobin's Q. Therefore, the model of the seventh hypothesis can be illustrated as the following:

$$
Y_{3}=2.105-0.033 \text { SDCit }-0.202 \text { FSit }+0.338 \text { SGit }
$$

The eighth hypothesis is significant and has negative relationship with Tobin's $Q$. This means that as long-term debt increases, the corporation's Tobin's Q ratio will be decreased. In other words, 1 unit increase in long-term debt will result in 0.073 unit decrease in Tobin's Q. Therefore, the model of the eighth hypothesis can be illustrated as the following:

$$
Y_{3}=2.228-0.073 \text { LDCit }-0.229 \text { FSit }+0.32 \text { SGit }
$$

The ninth hypothesis is significant and has a negative relationship with Tobin's $Q$. This means that as total debt increases, the corporation's Tobin's $\mathrm{Q}$ ratio will be decreased. In other words, 1 unit increase in long-term debt will result in 0.023 unit decrease in Tobin's Q. Therefore, the model of the ninth hypothesis can be illustrated as the following:

$$
Y_{3}=2.106-0.023 \text { TDCit }-0.203 \text { FSit }+0.333 \text { SGit }
$$

\section{Discussion and Conclusion}

The summary of hypotheses testing results is shown in table 6 . 
Table 6. Summary of Hypothesizes Results

\begin{tabular}{|c|c|c|c|}
\hline Hypotheses & Results & $\begin{array}{c}\text { Coefficient of the Main Independent } \\
\text { Variable }\end{array}$ & $\mathbf{R}^{2}$ \\
\hline $\begin{array}{l}\text { There is a significant relationship between short-term debt policy and gross } \\
\text { profit margin. }\end{array}$ & Confirmed & -0.07 & $51 \%$ \\
\hline $\begin{array}{l}\text { There is a significant relationship between long-term debt policy and gross } \\
\text { profit margin. }\end{array}$ & Rejected & - & - \\
\hline $\begin{array}{l}\text { There is a significant relationship between total debt policy and gross } \\
\text { profit. }\end{array}$ & Confirmed & -0.1121 & $50 \%$ \\
\hline $\begin{array}{l}\text { There is a significant relationship between short-term debt policy and } \\
\text { return on assets. }\end{array}$ & Confirmed & -0.0912 & $61 \%$ \\
\hline $\begin{array}{l}\text { There is a significant relationship between long-term debt policy and return } \\
\text { on assets. }\end{array}$ & Confirmed & -0.0921 & $58 \%$ \\
\hline $\begin{array}{l}\text { There is a significant relationship between total debt policy and return on } \\
\text { assets. }\end{array}$ & Confirmed & -0.021 & $49 \%$ \\
\hline $\begin{array}{l}\text { There is a significant relationship between short-term debt policy and } \\
\text { Tobin's Q Ratio. }\end{array}$ & Confirmed & -0.033 & $65 \%$ \\
\hline $\begin{array}{l}\text { There is a significant relationship between long-term debt policy and } \\
\text { Tobin's Q Ratio. }\end{array}$ & Confirmed & -0.073 & $63 \%$ \\
\hline $\begin{array}{l}\text { There is a significant relationship between total debt policy and Tobin's } \\
\text { Q Ratio. }\end{array}$ & Confirmed & -0.023 & $64 \%$ \\
\hline
\end{tabular}

Corporations need capital in order to improve and grow. A part of the capital can be provided from internal resources of a corporation such as retained earnings which is obtained from corporation's profit and is not divided among shareholders. The rest of the capital can be borrowed or be provided from capital markets. Managers have to develop efficient debt policies in order to suitably face financial issues. Debt policies are related to the corporation's value and a change in financial leverage will lead to a change in total cost of a capital and the corporation's total value. In brief, the relationship between the capital's structure and the corporations' performance shows that there is a negative relationship between loans' policies and corporations' performance. The capital's structure especially short-term loans and total debt have negative relationships with corporations' performance.

According to statistical results, the claims of this research have been confirmed in a 5\% error level. Hence, it can be concluded that an increase in debts (short-term, long-term, and total debts) will result in a decrease in corporations' performance. Of course, it does not mean the corporation should decrease debts as there are other factors which might have affected its performance. Therefore, it seems the amounts of the corporation's debts should be defined with regard to its size and other factors. If corporations provide their assets only from their debts and don't pay any attention to their sizes, their performance will not be improved substantially. Another explanation of the results is that investigated corporations don't have optimized capital structures. In other words, corporations have tried to increase their debt ratio and move toward an optimized ratio of debt to equity. It seems that even this matter has not been accomplished. The results of this study is consistent with studies of Abor (2007), Abu Alsayyed Abid (2009), and Zaitun \& Tian (2007). All of these studies express negative inflouence of debt on corporations' performance.

\section{References}

Abdel Shahid, S. (2003). Does ownership structure affect firm value? Evidence from the Egyptian stock market. Working Paper. http://dx.doi.org/10.2139/ssrn.378580

Abor, J. (2005). The effect of capital structure on profitability: an empirical analysis of listed firms in Ghana. Journal of Risk Finance, 6(5), 438-445. http://dx.doi.org/10.1108/15265940510633505

Abor, J. (2007). Debt policy and performance of SMEs. Journal of Risk Finance, 8(4), 364-379. http://dx.doi.org/10.1108/15265940710777315

Ashrafzadeh, S. H., \& Mehregan, N. (2010). Panel data econometrics. Tehran: Tehran University Publications, 1st edition.

Azar, A., \& Momeni, M. (2006). Statistics and its application in management. Samt Publications, 8th edition. 
Berger A. N., Bonaccorsi di Patti, E. (2004). Capital structure and firm performance: A new approach to testing agency theory and an application to the banking industry. Journal of Banking \& Finance, 30(4), 1065-1102. http://dx.doi.org/10.1016/j.jbankfin.2005.05.015

David, D. F., \& Olorunfemi, S. (2010). Capital structure and corporate performance in Nigeria petroleum Industry: panel data analysis. Journal of Mathematics and Statistics, 6(2), 168-173. http://dx.doi.org/10.3844/jmssp.2010.168.173

El-Sayed Ebaid, I. (2009). The impact of capital-structure choice on firm performance: empirical evidence from Egypt. Journal of Risk Finance, 10(5), 477-487. http://dx.doi.org/10.1108/15265940911001385

Gleason, K. C., Mathur, L. N., \& Mathur, I. (2000). The interrelationship between culture, capital structure, and performance: Evidence from European retailers. Journal of Business Research, 50(2), 185-191. http://dx.doi.org/10.1016/S0148-2963(99)00031-4

Gujarati, D. N. (2004). Basic Econometrics. New York: McGraw Hill, 4th edition, Chapters 1, $12,17$.

Hamidizadeh, M. R., Baramound, S., \& Latifi M. (2012). Empowerment And Contextual Performance with Job Utility's Model. Interdisciplinary journal of contemporary research in business, 3(9), 1199-1218.

Hamidizadeh, M. R., Yazdani, N., Alemtabriz, A., \& Latifi M. (2012). Designing and Validating a Systematic Model of E-Advertising. International Journal of Marketing Studies, 4(2), 130-149. http://dx.doi.org/10.5539/ijms.v4n2p130

Latifi, M., \& Azimi, H. (2010). Establishing a Marketing Plan for NOWDAR Company Applying a Taxonomy Method. International Conference on Management Science and Information Engineering (ICMSIE 2010), Zhongzhou, China.

Latifi, M., Azimi, H., \& Forougozar, H. (2011). Recognizing the Influencing Factors on Technology Applying TOPSIS Technique: A Case -Control Study of an E-commerce Company. 2nd International Conference on e-Education, e-Business, e-Management and e-Learning (IC4E 2011), Mumbai, India.

Latifi, M., Azimi, H., Sepehr Sadeghian, N., \& Talebipour Aghabagher, Z. (2012). Exploring and Evaluating the Effects of Strategic Positioning on Firms Performance with Regard to Physical and Perceptual Positioning. International Business and Management Journal, 4(2), 116-122.

Latifi, M., Ghalambor, M., \& Azimi, H. (2012). Indexing, Evaluating, and Ranking the Challenges Facing the Establishment of Investment Banking (of Funding Organizations) in Iran. Journal of Money, Investment and Banking, 24, 49-59.

Long, W. F., \& Ravenscraft, D. J. (1984). The misuse of accounting rates of return: Comment. American Economic Review, 74, 494-500.

Majumdar, S. K., \& Chhibber, P. (1999). Capital structure and performance: Evidence from a transition economy on an aspect of corporate governance. Public Choice, 98, 287-305. http://dx.doi.org/10.1023/A:1018355127454

Margaritis, D., \& Psillaki, M. (2010). Capital structure, equity ownership and firm performance. Journal of Banking \& Finance, 34(3), 621-632. http://dx.doi.org/10.1016/j.jbankfin.2009.08.023

McConnell, J. J., \& Servaes, H. (1990). Additional evidence on equity ownership and corporate value. Journal of Financial Economics, 27, 595-612. http://dx.doi.org/10.1016/0304-405X(90)90069-C

Morck, R., Shleifer A., \& Vishny, R. (1988). Management ownership and market valuation: An empirical analysis. Journal of Financial Economics, 20, 293-315. http://dx.doi.org/10.1016/0304-405X(88)90048-7

Qi, D., Wu, W., \& Zhang, H. (2000). Shareholding structure and corporate performance of partially privatized firms: Evidence from listed Chinese companies. Pacific-Basin Finance Journal, 8(5), 587-610. http://dx.doi.org/10.1016/S0927-538X(00)00013-5

Reese, J. S., \& Cool, W. R. (1978). Measuring investment centre performance. Harvard Business Review, 56, $28-46$.

Zeitun, R., \& Tian, G. (2007). Capital structure and corporate performance: Evidence from Jordan. Australasian Accounting Business and Finance Journal, 1, 40-53.

Zhou, X. (2001). Understanding the determinants of managerial ownership and the link between ownership and performance: Comment. Journal of Financial Economics, 62, 559-571. http://dx.doi.org/10.1016/S0304-405X(01)00085-X 